University of Nebraska - Lincoln

DigitalCommons@University of Nebraska - Lincoln

Faculty Publications: Department of

Entomology

Entomology, Department of

$4-30-2019$

\title{
Spatial Patterns and Sequential Sampling Plans for Estimating Densities of Stink Bugs (Hemiptera: Pentatomidae) in Soybean in the North Central Region of the United States
}

\author{
Daniela T. Pezzini \\ University of Minnesota, pezzi004@umn.edu \\ Christina D. DiFonzo \\ Michigan State University, difonzo@msu.edu \\ Deborah L. Finke \\ University of Missouri-Columbia, finked@missouri.edu \\ Thomas Hunt \\ University of Nebraska-Lincoln, thunt2@unl.edu \\ Janet J. Knodel \\ North Dakota State University, janet.knodel@ndsu.edu
}

See next page for additional authors
Follow this and additional works at: https://digitalcommons.unl.edu/entomologyfacpub

Part of the Entomology Commons

Pezzini, Daniela T.; DiFonzo, Christina D.; Finke, Deborah L.; Hunt, Thomas; Knodel, Janet J.; Krupke, Christian H.; McCornack, Brian P.; Michel, Andrew P.; Moon, Roger D.; Philips, Christopher R.; Varenhorst, Adam J.; Wright, Robert; and Koch, Robert, "Spatial Patterns and Sequential Sampling Plans for Estimating Densities of Stink Bugs (Hemiptera: Pentatomidae) in Soybean in the North Central Region of the United States" (2019). Faculty Publications: Department of Entomology. 824.

https://digitalcommons.unl.edu/entomologyfacpub/824

This Article is brought to you for free and open access by the Entomology, Department of at DigitalCommons@University of Nebraska - Lincoln. It has been accepted for inclusion in Faculty Publications: Department of Entomology by an authorized administrator of DigitalCommons@University of Nebraska - Lincoln. 


\section{Authors}

Daniela T. Pezzini, Christina D. DiFonzo, Deborah L. Finke, Thomas Hunt, Janet J. Knodel, Christian H. Krupke, Brian P. McCornack, Andrew P. Michel, Roger D. Moon, Christopher R. Philips, Adam J. Varenhorst, Robert Wright, and Robert Koch 


\title{
Spatial Patterns and Sequential Sampling Plans for Estimating Densities of Stink Bugs (Hemiptera: Pentatomidae) in Soybean in the North Central Region of the United States
}

\author{
Daniela T. Pezzini, ${ }^{1}$ Christina D. DiFonzo, ${ }^{2}$ Deborah L. Finke, ${ }^{3}$ \\ Thomas E. Hunt, ${ }^{4}$ Janet J. Knodel, ${ }^{5}$ Christian H. Krupke, ${ }^{6}$ \\ Brian McCornack, ${ }^{7}$ Andrew P. Michel, ${ }^{8}$ Roger D. Moon, ${ }^{1}$ \\ Christopher R. Philips, ${ }^{1}$ Adam J. Varenhorst, ${ }^{9}$ \\ Robert J. Wright, ${ }^{10}$ and Robert L. Koch ${ }^{1}$ \\ 1 Department of Entomology, University of Minnesota, 1980 Folwell Avenue, Saint Paul, \\ MN 55108 \\ 2 Department of Entomology, Michigan State University, 243 Natural Science Building, East \\ Leasing, MI 48824-1311 \\ 3 Division of Plant Sciences, University of Missouri-Columbia, Columbia, MO 65211 \\ 4 Haskell Agricultural Laboratory, Department of Entomology, University of Nebraska, \\ 57905866 Road, Concord, NE 68728 \\ 5 Department of Plant Pathology, North Dakota State University, 210 Walster Hall, Fargo, \\ ND 58108-6050 \\ 6 Department of Entomology, Purdue University, 901 West State Street, West Lafayette, IN \\ 47907 \\ 7 Department of Entomology, Kansas State University, 123 W. Waters Hall, 1603 Old Claflin \\ Place, Manhattan, KS 66506 \\ 8 Department of Entomology, Ohio Agricultural Research and Development Center, The \\ Ohio State University, 210 Thorne, 1680 Madison Avenue, Wooster, OH 4469 \\ 9 Department of Agronomy, Horticulture and Plant Science, South Dakota State University, \\ SAG 220, Brookings, SD 57007 \\ 10 Department of Entomology, University of Nebraska-Lincoln, 213 Entomology Hall, \\ Lincoln, NE 68583-0816
}

Corresponding author — Robert L. Koch, email koch0125@umn.edu

Published in Journal of Economic Entomology, 112:4 (2019), pp 1732-1740.

doi: $10.1093 /$ jee/toz100

Copyright (c) 2019 by the authors. Published by Oxford University Press on behalf of Entomological Society of America. Used by permission.

Submitted 3 December 2018; accepted 27 March 2019; published 30 April 2019. 


\begin{abstract}
Stink bugs are an emerging threat to soybean (Fabales: Fabaceae) in the North Central Region of the United States. Consequently, region-specific scouting recommendations for stink bugs are needed. The aim of this study was to characterize the spatial pattern and to develop sampling plans to estimate stink bug population density in soybean fields. In 2016 and 2017, 125 fields distributed across nine states were sampled using sweep nets. Regression analyses were used to determine the effects of stink bug species [Chinavia hilaris (Say) (Hemiptera: Pentatomidae) and Euschistus spp. (Hemiptera: Pentatomidae)], life stages (nymphs and adults), and field locations (edge and interior) on spatial pattern as represented by variance-mean relationships. Results showed that stink bugs were aggregated. Sequential sampling plans were developed for each combination of species, life stage, and location and for all the data combined. Results for required sample size showed that an average of 40-42 sample units (sets of 25 sweeps) would be necessary to achieve a precision of 0.25 for stink bug densities commonly encountered across the region. However, based on the observed geographic gradient of stink bug densities, more practical sample sizes (5-10 sample units) may be sufficient in states in the southeastern part of the region, whereas impractical sample sizes ( $>100$ sample units) may be required in the northwestern part of the region. Our findings provide research-based sampling recommendations for estimating densities of these emerging pests in soybean.
\end{abstract}

Keywords: soybean, stink bug, Taylor's power law, insect sampling

The North Central Region of the United States ranks first for soybean, Glycine max (L.) Merr. (Fabales: Fabaceae), production, accounting for $82 \%$ of the national soybean acreage (USDA-NASS 2018). The soybean aphid, Aphis glycines Matsumura (Hemiptera: Aphididae), is currently the most important insect pest of soybean in the region (Ragsdale et al. 2007, Hurley and Mitchell 2014). However, stink bugs are an increasing concern for soybean in this region for several reasons (Koch et al. 2017). The brown marmorated stink bug, Halyomorpha halys (Stal) (Hemiptera: Pentatomidae), a significant pest of fruit, vegetable, and field crops on the East Coast, is currently invading the North Central Region of the United States (Leskey et al. 2012, Rice et al. 2014). In addition, there has been an increasing abundance of native stink bug species, including green [Chinavia hilaris (Say) (Hemiptera: Pentatomidae)], brown [Euschistus servus (Say) (Hemiptera: Pentatomidae)], one-spotted [E. variolarius (Palisot de Beauvois) (Hemiptera: Pentatomidae)], and red-shouldered [Thyanta custator accerra McAtee (Hemiptera: Pentatomidae)] stink bugs in field crops (Hunt et al. 
2011, 2014; Michel et al. 2015). Stink bugs feed on soybean seeds and pods using piercing-sucking mouthparts, which results in lower seed quality and yield (McPherson and McPherson 2000). Region-specific management recommendations are needed (Koch et al. 2017).

Research programs, as with integrated pest management programs, rely on accurate sampling to estimate insect densities in the field as closely as possible to the true density (Naranjo and Hutchison 1997, Moon and Wilson 2008, Pedigo and Rice 2009). Sampling methods for estimating stink bug density in soybean include the use of sweep nets, which is reported to be more cost-effective than other traditional sampling methods (Todd and Herzog 1980, Sane et al. 1999) and more efficient at lower insect densities (Reay-Jones et al. 2009). In the North Central Region of the United States, 23 species of stink bugs are likely to occur in soybean fields (Koch et al. 2017), with $C$. hilaris and species of Euschistus being the most abundant (Koch and Pahs 2014, Koch and Rich 2015, Pezzini 2018).

Sampling plans can be grouped in different categories (i.e., detection, estimation, and decision sampling) that are used for different purposes (Moon and Wilson 2008). Reliability of estimation sampling plans is determined by the precision level, measured by the variance in estimated sample means (i.e., sample standard error) relative to their associated means (Todd and Herzog 1980, Moon and Wilson 2008). Low precision estimates could be unreliable for research purposes because they may misrepresent actual insect density. Currently, sampling recommendations for estimation of stink bug abundance in soybean fields vary across the United States (Table 1), and to our knowledge, associated precision levels have not been characterized for these recommendations. Sequential sampling for estimation uses a pre-established precision level to estimate pest density in the field (Naranjo and Hutchison 1997, Todd and Herzog 1980). Because of their flexibility in adjusting sample size relative to the number of insects collected, sequential sampling plans ensure that no more samples are collected than necessary, by considering the desired precision level aimed to be achieved with sampling (Todd and Herzog 1980). Sequential sampling plans are preferred because they save time and may achieve a higher precision level than conventional methods (i.e., fixed sample size sampling plans; Todd and Herzog 1980, Hodgson et al. 2004, Galvan et al. 2007, Reay-Jones et al. 2009). 
Table 1. Scouting recommendations for stink bug sampling in soybean in the United States

\begin{tabular}{lcc} 
Entity & Sample unit size & Sample size $^{b}$ \\
& 10 & 2 \\
Clemson University $^{1}$ & 100 & - \\
Mississippi State University & 10 & 5 \\
NCSRP3 $^{3}$ & 15 & 12 \\
North Carolina State University $^{4}$ & 10 & $' 3-5^{\prime}$ \\
Ohio State University $^{5}$ & 20 & - \\
Purdue University $^{6}$ & 100 & - \\
Texas A\&M University $^{7}$ & 50 & Increases with \\
University of Kentucky & & field size \\
University of Missouri9 & - & 'Several' \\
University of Tennessee & 100 & - \\
University of Wisconsin & & 5 \\
\hline
\end{tabular}

'-' means information not indicated.

a. Number of sweeps per sample unit.

b. Number of sample units.

Sources: 1) Greene (2017), 2) Mississippi State University (2019), 3) Raudenbush et al. (2017),

4) Reisig (2017), 5) Michel et al. (2015), 6) Krupke and Obermeyer (2017), 7) Vyavhare et al.

(2015), 8) University of Kentucky https://ipm.ca.uky.edu/content/green-stinkbug-soybeans,

9) Boyd and Bailey (2000), 10) Stewart et al. (2010), and 11) Cullen (2012).

The development of appropriate sampling plans for insects requires an understanding of the spatial pattern of the target insect, which may vary with species, abundance, life stage, landscape composition, and sample unit employed (Taylor 1961, Vinatier et al. 2011). Where insects are counted in sample units that are arranged spatially, then spatial pattern affects variance in counts around the sample mean. Taylor's power law is a robust regression method that describes the variance-mean relationship and thereby characterizes the spatial pattern of that subject organism (Taylor 1961). Green's method, a type of fixed-precision sequential sampling for estimation, uses parameters from Taylor's power law regressions to characterize the spatial pattern of the pest for calculation of sampling stop lines (i.e., when sampling achieves the predetermined precision level; Green 1970).

Stink bugs are polyphagous pests, and their spatial and temporal dynamics depend on the availability of food resources and patterns of field colonization (McPherson and McPherson 2000, Panizzi et al. 2000). Adults move to soybean fields in midsummer when soybeans reach reproductive growth stages (i.e., developing pods and seeds; McPherson and McPherson 2000, Panizzi et al. 2000, Koch and Rich 2015). Within fields, stink bug densities tend to be greater at field 
edges (Tillman et al. 2009, Reeves et al. 2010, Leskey et al. 2012). During the colonization process, stink bug females lay clusters of eggs on leaves (Panizzi et al. 2000). First instars emerging from these eggs generally do not feed on the plants and remain aggregated near the egg mass, probably for symbiont acquisition (McPherson and McPherson 2000, Esquivel and Medrano 2014). The subsequent four instars disperse to feed on plant material, but remain relatively close to the oviposition site until they reach the winged adult stage that readily colonizes other parts of the field or other habitats (McPherson and McPherson 2000).

The goals of this study were to characterize the spatial pattern of stink bugs in soybean fields in the North Central Region and to develop and validate a sequential sampling plan to estimate stink bug population densities in the region. Results of this study are essential to improve sampling for research on stink bugs as they increase in abundance and importance in this key soybean production area of the United States.

\section{Materials and Methods}

\section{Field Sites}

A standardized protocol was used to sample stink bugs in soybean fields distributed across the North Central Region of the United States. In 2016, 63 fields were sampled in eight states: Indiana, Kansas, Minnesota, Missouri, Nebraska, North Dakota, Ohio, and South Dakota (Table 2). In 2017, 62 fields were sampled from the same eight states, plus Michigan. In general, fields in each state were at one to four separate sites, with one to four fields per site. Sites were 13-368 km apart within states and were located at university research stations or cooperating farms. Field sizes ranged from 0.3 to 120 ha (mean \pm SEM: 17.6 $\pm 1.8 \mathrm{ha}$ ), row spacing was $76.2 \mathrm{~cm}$, and soybean varieties, planting dates, and management practices were representative of the respective states. Fields were generally sampled on a weekly basis from beginning-bloom (R1) through full maturity (R8) soybean growth stages (Fehr and Caviness 1977), which spanned approximately mid-July to late September. A grand total of 125 fields were sampled during the 2 yr combined. 
Table 2. Number of soybean fields sampled for stink bugs with sweep nets in cooperating states in the North Central Region of the United States, by study year

\begin{tabular}{lcc} 
State & 2016 & 2017 \\
\hline Indiana & 8 & 8 \\
Kansas & 8 & 7 \\
Michigan & 0 & 8 \\
Minnesota & 12 & 8 \\
Missouri & 8 & 4 \\
Nebraska & 7 & 8 \\
North Dakota & 8 & 8 \\
Ohio & 8 & 8 \\
South Dakota & 4 & 3 \\
Total & 63 & 62 \\
\hline
\end{tabular}

\section{Data Collection}

In each field, sampling was stratified with sample units collected from a field edge (i.e., less than $10 \mathrm{~m}$ into the field) and from the field interior (i.e., more than $10 \mathrm{~m}$ into the field; Leskey et al. 2012, Venugopal et al. 2014). A sample unit consisted of a set of 25 pendulumstyle sweeps through the upper canopy of two adjacent soybean rows using a 39-cm-diameter sweep net. Each pass of the net counted as one sweep, and consecutive sweeps were arranged in a 'Lazy-8' pattern (Kogan and Pitre 1980). Sample units were spaced at least $10 \mathrm{~m}$ apart. In most locations, four sample units were collected from the field edge, and eight sample units were collected from field interior on each sample date. However, in two locations in Minnesota, additional sample units (up to 50 sample units per field per sample date) were occasionally collected. After each set of 25 sweeps was collected, the net was emptied into a $20.3 \times 25.4 \mathrm{~cm}$ plastic zipper-locking bag (Reloc Zippit, Lima, OH) and labeled by date and location.

Bags were frozen soon after collection, rough sorted to extract stink bugs, and then specimens were shipped to the University of Minnesota for identification and quantification. Nymphs were identified to genus using DeCoursey and Esselbaugh (1962) and Evans (1985), and adults were identified to species and subspecies using keys in McPherson and McPherson (2000), Rider (2012), and Paiero et al. (2013). Voucher specimens of each species were placed in the University of Minnesota Insect Collection in St. Paul, MN. 


\section{Assessment of Spatial Patterns}

Based on Kogan and Herzog (1980), we use the term 'spatial pattern' as opposed to other commonly used terminology, such as 'spatial distribution' or 'spatial dispersion'. The spatial pattern of stink bugs was assessed for each combination of stink bug species, life stage, and location by calculating arithmetic means and variances of the number of stink bugs for each set of sweep net samples (i.e., collection of sample units from a given field on a given sample date). The relationships between matching sample variances and means were analyzed using Taylor's power law equation $s^{2}=a m^{b}$, where $s^{2}$ is sample variance, $m$ is sample mean, $a$ is a sampling parameter, and $b$ is an index of aggregation (Taylor 1961). From regression of matching $\log _{10}$-transformed sample variances on $y$-axis and $\log _{10}$ transformed means on $x$-axis, the parameter $a$ of Taylor's power law is estimated by the antilog of the regression's intercept, and $b$ is estimated by the regression's slope.

The parameter $b$ can range from $b<1$ to $b=1$ to $b>1$, indicating uniform, random, or aggregated spatial patterns, respectively (TayIor 1961). Determination of stink bug spatial patterns was performed by comparing $b$ values to 1 using $t$-tests with $\mathrm{df}=n-2$ and $P=0.05$ (Wilson 1985, Zar 1999). Excluding samples from fields where stink bugs were absent, spatial patterns were examined in a total of 1,416 data sets involving different field locations, stink bug species, and life stages.

Spatial patterns in all of the data sets were examined by fitting a generalized linear mixed model using the 'Ime4' package (Bates et al. 2015) in $R$ version 3.4.3 (R Core Team 2018). Log variance was the response variable, and fixed effects were log mean, stink bug species, location in field (i.e., interior and edge), life stage (i.e., adult and nymph), and two- and three-way interactions. Random effects were year and state. Significance was determined by likelihood ratio $\chi^{2}$ tests. A significant interaction between a regression's slope (i.e., log mean) and any of the other fixed effects indicated that slopes varied among corresponding species, life stages, or locations. Backward elimination was used to omit nonsignificant $(P>0.05)$ main effects or interactions. Marginal $R$-squared $\left(r^{2}\right)$ for each regression was calculated using the package 'MuMln' (Bartoń 2018). 


\section{Sampling Plan Development}

Stop lines for sequential sampling plans were developed from 1,416 data sets (i.e., samples split by species, life stage, and location) from individual field visits. Green's method defines stop lines as $T_{n} \geq\left(a n^{1-b} / D\right)$ $1 /(2-b)$, where $T_{n}$ is cumulative number of stink bugs, $n$ is growing number of sample units, $D$ is desired precision (SEM/mean), and $a$ and $b$ are parameters of Taylor's power law (Green 1970, Naranjo and Flint 1994). Desired precision was set at 0.25 , a recommended level for pest sampling purposes (Southwood 1978), which has been used to develop sampling plans by others (e.g., Naranjo and Hutchison 1997, Hodgson et al. 2004). Stop lines were calculated for a minimum of $n$ = 4 sample units, which is the smallest sample size recommended for sampling stink bugs in rice, Oryza sativa L. (Poales: Poaceae) (Espino et al. 2008), in cotton, Gossypium hirsutum L. (Malvales: Malvaceae) (Reay-Jones et al. 2009), and more generally for arthropods in soybean (Kogan and Pitre 1980).

We compared stop lines for different stink bug species, life stages, and field locations by examining their respective $83 \%$ confidence intervals for overlap (Payton et al. 2003). This approach was used to account for the inflation of errors when multiple treatments with similar standard errors are compared (Payton et al. 2003). Confidence intervals were calculated with the boot procedure (Canty and Ripley 2017) in $R$, with sample sizes of 1,000 estimates of Taylor's power law parameters from relevant subsets of the original sample data, resampled with replacement. In turn, we calculated 8.5th and 91.5th percentiles for $T_{n}$ s over a realistic range of chosen sample sizes. Because few of the stop lines among species, life stages, and field locations were judged to be different based on the overlap of confidence intervals, the data sets were combined, and a single sequential sampling plan was developed for more practical use by researchers through the region. Stop lines for the combined sequential sampling plan were developed from 526 of the 549 data sets from individual field visits (i.e., samples) and followed the same steps described previously. The remaining 23 data sets were reserved for subsequent validation of the sampling plan. 


\section{Required Sample Size for Population Estimates}

Using the 549 data sets of our study, we calculated the minimum number of sample units required to estimate stink bug density in soybean fields with a given level of reliability based on the method by Green (1970), $N=a m^{b-2} / D^{2}$, where $a$ and $b$ are Taylor's power law parameters, $m$ is insect mean density, and $D$ is the desired precision level, set at 0.25 . Furthermore, the combined sequential sampling plan developed above was validated using Resampling for Validation of Sampling Plans (RVSP) v. 2.0, following methods of Naranjo and Hutchison (1997). Simulations were performed by randomly selecting samples with replacement from the validation data sets until the corresponding stop line was exceeded. If resulting average precision values were better than the desired precision values, desired precision was relaxed to obtain the average desired precision (Burkness and Hutchison 1997, Galvan et al. 2007, Tran and Koch 2017). Resampling analysis to determine the sample sizes required to attain the desired precision was based on 500 resampling iterations of each data set. The resulting sample sizes were averaged across validation data sets to obtain the average sample number (ASN) for estimating stink bugs in soybean fields over the ranges of densities of stink bugs experienced in the 23 validation data sets (i.e., samples). In addition, based on the above sampling plan, more practical sample sizes falling in the range of current recommendations (Table 1) were assessed for resulting levels of precision. Particularly, simulations were performed by adjusting desired precision levels to achieve a targeted ASN of 6 and 10 sample units.

\section{Results and Discussion}

In total, 373 and 381 samples were collected in 2016 and 2017, respectively. Across years, a total of 1,973 adults and 3,857 nymphs of Euschistus spp. and C. hilaris were collected, with densities ranging from 0.04 to 14.9 stink bugs per 25 sweeps (mean of 1.2 stink bugs per 25 sweeps). Analyses and sample plan development focused on C. hilaris and Euschistus spp. because these species have the potential to damage soybean in the North Central Region of the United States 
(Koch et al. 2017, Pezzini 2018), and they represented over 95\% of all individual stink bugs collected. Euschistus spp. were more prevalent (86\% of the total) in northwestern states in the region (i.e., Kansas, Michigan, Minnesota, Nebraska, North Dakota, and South Dakota), whereas $C$. hilaris was more prevalent (65\% of the total) in southeastern states (i.e., Indiana, Missouri, and Ohio). Euschistus spp. consisted of six species and subspecies [E. variolarius, E. s. servus (Say) (Hemiptera: Pentatomidae), E. s. euschistoides (Vollenhoven) (Hemiptera: Pentatomidae), E. servus hybrid, E. tristigmus tristigmus (Say) (Hemiptera: Pentatomidae), and E. t. luridus Dallas (Hemiptera: Pentatomidae)]. Additional stink bug species observed in our study represented less than $6 \%$ of the total number of stink bugs, and they were low in abundance (0-0.03 stink bugs per 25 sweeps). Therefore, these species were not included in our analyses. Results of species abundance observed here were consistent with earlier reports (McPherson and McPherson 2000, Koch et al. 2017).

\section{Assessment of Spatial Patterns}

Slopes and intercepts of log-transformed Taylor's power law regressions from the 1,416 data sets (i.e., samples split by species, life stage, and location) differed significantly among the principal stink bug species (Euschistus spp. vs C. hilaris), their life stages (nymphs vs adults), and locations within fields (edge vs interior; Table 3). These statistical differences justified separation of the data for species-, stage- and

Table 3. Summary of $\chi^{2}$ tests for significance of effects of log sample means, stink bug species (Chinavia hilaris and Euschistus spp.), life stages (nymphs and adults), and field locations (field edge and interior) on log sample variances among sweep net samples from soybean fields in nine states in the North Central Region of the United States, 2016 and 2017

\begin{tabular}{lrrr} 
Variables $^{a}$ & $\chi^{2}$ & $d f$ & $P$ \\
\hline Log mean & 6554.4 & 1 & $<0.001$ \\
Species & 9.6 & 1 & 0.002 \\
Life stage & 1.1 & 1 & 0.303 \\
Location & 10.7 & 1 & 0.001 \\
Log mean $\times$ Species & 17.7 & 1 & $<0.001$ \\
Species $\times$ Location & 6.3 & 1 & 0.011 \\
Log mean $\times$ Life stage $\times$ Species & 10.2 & 1 & 0.001
\end{tabular}

a. Nonsignificant interactions of main effects were removed from table. 
Table 4. Summary of regression analyses of log sample variances on log sample means for counts of Chinavia hilaris and Euschistus spp. nymphs and adults in edges and interiors of soybean fields in the North Central Region of the United States

\begin{tabular}{llllllll} 
Species & Life stage Location & $n^{a}$ & $a(95 \% \mathrm{Cl})$ & $b(95 \% \mathrm{Cl})$ & $t$ value $(b=1)$ & $r^{2}$ \\
\hline \multirow{2}{*}{ Chinavia hilaris } & \multirow{2}{*}{ Adult } & Edge & 110 & $1.04(0.94,1.16)$ & $1.06(0.96,1.16)$ & $2.1^{*}$ & 0.71 \\
& & Interior & 97 & $1.34(1.14,1.58)$ & $1.13(1.02,1.23)$ & $3.4^{*}$ & 0.82 \\
& \multirow{2}{*}{ Nymph } & Edge & 90 & $1.35(1.22,1.49)$ & $1.23(1.15,1.31)$ & $4.3^{*}$ & 0.84 \\
& & Interior & 83 & $1.63(1.44,1.84)$ & $1.26(1.17,1.34)$ & $4.6^{*}$ & 0.92 \\
Euschistus spp. & \multirow{2}{*}{ Adult } & Edge & 223 & $1.21(1.09,1.35)$ & $1.15(1.07,1.24)$ & $7.6^{*}$ & 0.81 \\
& & Interior & 262 & $1.05(0.92,1.20)$ & $1.03(0.96,1.11)$ & $2.1^{*}$ & 0.88 \\
& \multirow{2}{*}{ Nymph } & Edge & 271 & $1.04(0.96,1.12)$ & $1.04(0.98,1.11)$ & $2.0^{*}$ & 0.72 \\
& & Interior & 280 & $1.14(1.06,1.22)$ & $1.06(1.02,1.11)$ & $2.2^{*}$ & 0.87 \\
Combined $^{b}$ & & & 549 & $1.40(1.32,1.48)$ & $1.16(1.13,1.18)$ & $6.8^{*}$ & 0.93 \\
\hline
\end{tabular}

$\mathrm{Cl}$ (confidence interval).

a. Number of data sets.

$b$. Data combined across species, life stages, and locations.

${ }^{*} t$-test with $n-2$ degrees of freedom and $P=0.05$ indicated a significant departure of coefficient $b$ from a value of 1.

location-specific assessments of spatial patterns (Table 4). Regression models for all the data combined and for subsets involving each species-, life stage- and location-specific analyses had slopes (bs) that were statistically greater than one $(P<0.05)$, which indicated aggregated spatial patterns, at least at relatively high densities (Table 4).

Aggregated spatial patterns were previously described for stink bugs in soybean (Todd and Herzog 1980), rice (Espino et al. 2008), cotton (Reay-Jones et al. 2009, Tillman et al. 2009), and corn, Zea mays L. (Poales: Poaceae) (Babu and Reisig 2018). In our study, nymphs and adults of both C. hilaris and Euschistus spp. were aggregated in field edges and interiors, but they exhibited different levels of aggregation, which may be due to differences in stink bug density between species, life stages, and field locations (Tables 3 and 4).

Spatial pattern of an insect species is primarily determined by its behavior (Davis 1994), and the level of aggregation can differ among insect life stages (Taylor et al. 1961). For example, aggregation of $\mathrm{Ne}$ zara viridula (L.) (Hemiptera: Pentatomidae) adults in rice fields was related to the sexual attraction of males to females (Nakasuji et al. 1965). In addition, aggregation can also be mediated by substrate-borne vibrational signaling (Harris and Todd 1980, Lampson et al. 2013) and by species-specific aggregation pheromones produced by males that 
attract males, females, and nymphs (Aldrich et al. 1991, Tillman et al. 2010). Differences in spatial patterns between stink bug adults and nymphs are probably mediated by the ovipositional behavior of stink bug females and differences in dispersal capacity of the life stages. Specifically, females lay eggs in clusters and resulting nymphs have limited mobility until later instars compared with mobile winged adults (Kiritani et al. 1965, Reay-Jones et al. 2009). Different levels of aggregation among stink bug species have been observed in various crops such as wheat, Triticum aestivum L. (Poales: Poaceae), cotton, peanut, Arachis hypogaea L. (Fabales: Fabaceae), soybean, and corn (ReayJones 2014, Pilkay et al. 2015). Differences in the level of aggregation across locations in the field are probably driven by differences in the spatial and temporal colonization pattern and flight capacity of stink bug species in search of high-quality food sources (Tillman et al. 2009, Reay-Jones 2014, Pilkay et al. 2015, Wiman et al. 2015, Babu 2018).

\section{Sampling Plan Development}

To use sequential sampling plans for estimation, a crop scout tracks the cumulative number of stink bugs $\left(T_{n}\right)$ and the cumulative number of sample units $(n)$ in Fig. $\mathbf{1}$ and Fig. 2, and sampling ceases when the critical stop line is exceeded. In our study, results from regression analyses supported the separation of data by species, life stage, and location in the field. Therefore, sampling plans for each combination of these covariates were developed for a fixed precision of 0.25 (Fig. 1). Estimating the density of stink bugs by species, life stage, and/or location in the field may be of use for researchers with specific interests. Also, the availability of species-specific sampling plans is important because of the relative differences in geographic distribution and abundance of each species across the North Central Region of the United States (Pezzini 2018).

Species-, life stage-, and location-specific sampling plans may have value for detailed research purposes, but more generalized sampling recommendations may also be desirable. Though statistical differences in spatial patterns existed among species, life stages, and locations, confidence intervals developed for sequential sampling plan stop lines for each combination generally overlapped (Fig. 1), suggesting these sampling plans may be combined. Because injury thresholds for soybean are based on counts of nymphs and adults of all 

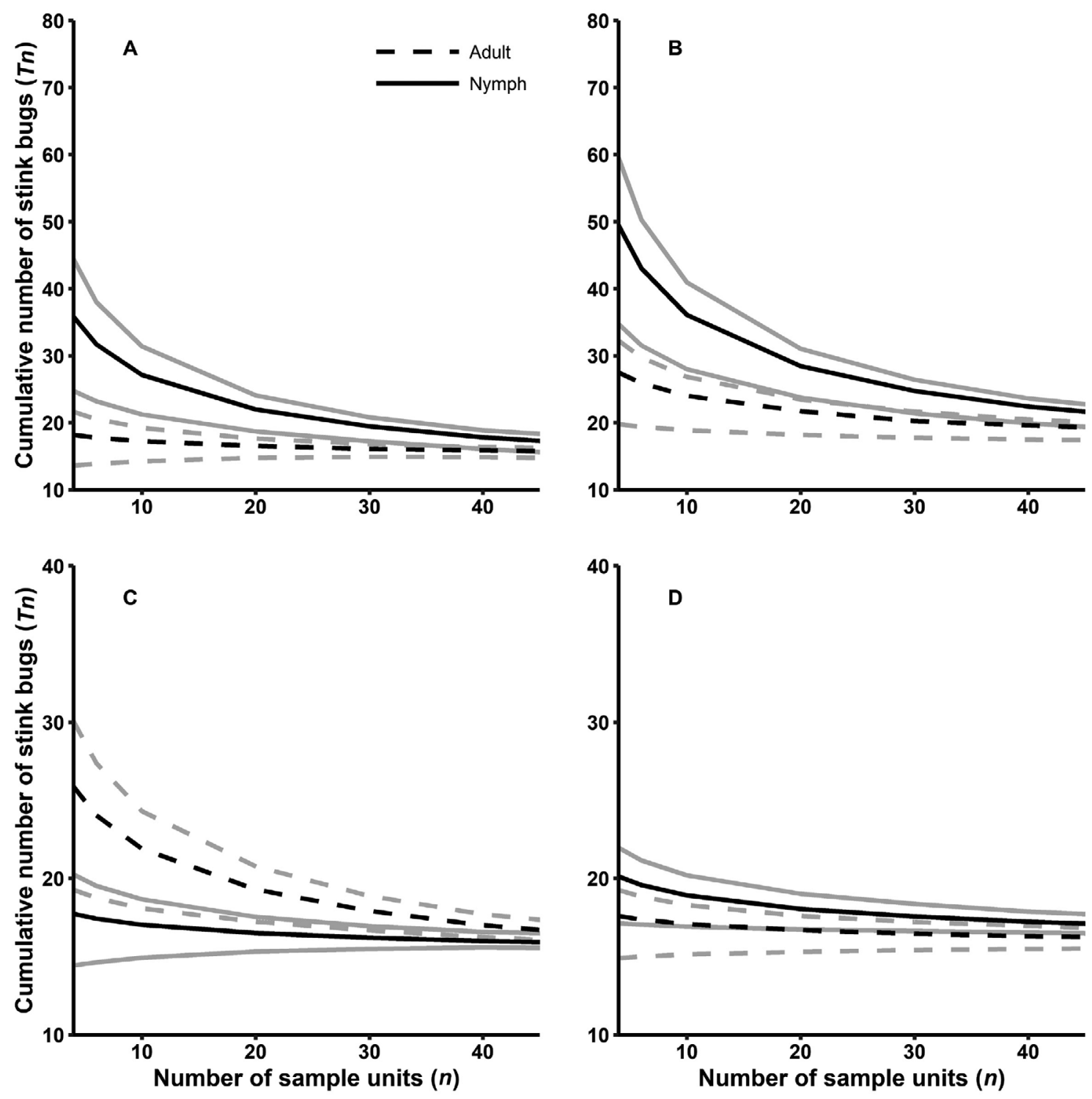

Fig. 1. Green's sequential sampling plans for estimating mean density of herbivorous stink bugs in soybean in the North Central Region of the United States, by species, life stage, and location in field, with 25-sweep sample units and precision level $=0.25$. Sampling plans for (A) Chinavia hilaris in field edges and (B) interiors and for (C) Euschistus spp. in field edges and (D) interiors. Black lines are stop lines for cumulative number of stink bugs ( $T n)$, and gray lines indicate bootstrap estimates of upper and lower $83 \%$ confidence limits for the stop lines.

herbivorous species combined (Boyd and Bailey 2000, McPherson and McPherson 2000, Stewart et al. 2010, Cullen 2012, Michel et al. 2015, Greene 2017, Koch et al. 2017, Raudenbush et al. 2017, Reisig 2017), and studies show different stink bug species (i.e., E. servus, N. viridula, 


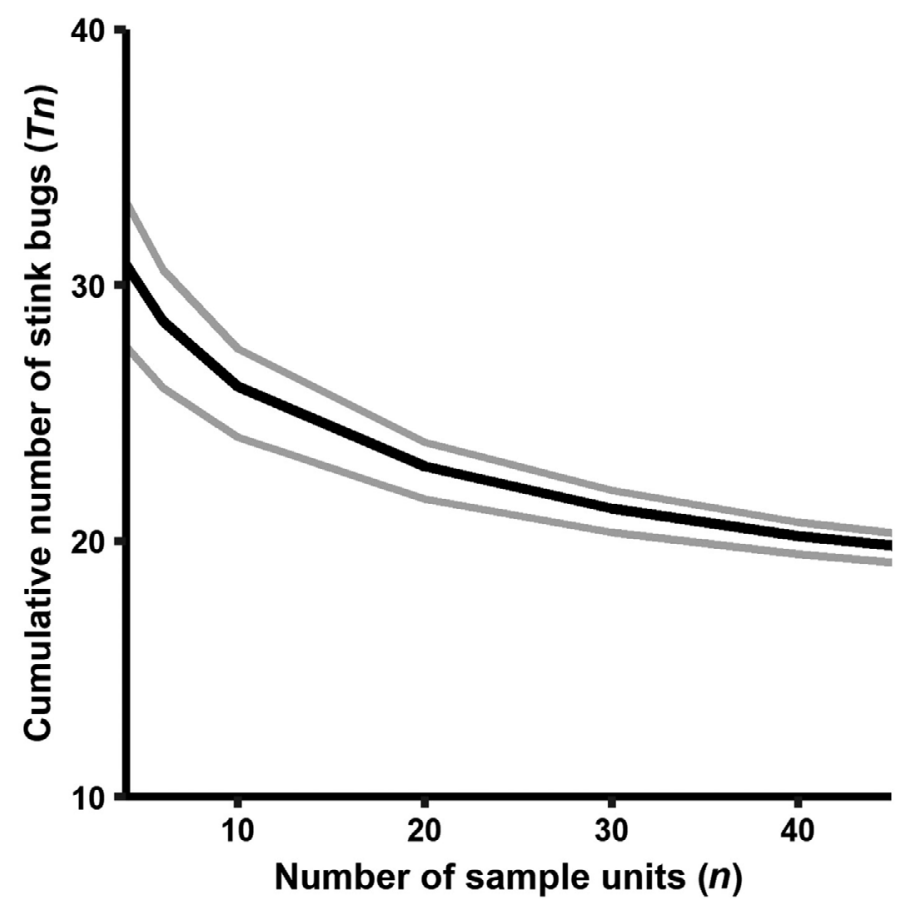

Fig. 2. Green's sequential sampling plan for estimating mean density of herbivorous stink bugs in soybean in the North Central Region of the United States, using 25-sweep sample units, combined across species, life stages, and field locations, and with precision level $=0.25$. Black line indicates stop line for cumulative number of stink bugs $(T n)$, and gray lines indicate upper and lower $83 \%$ confidence limits for the stop line.

C. hilaris) causing similar damage to soybean (McPherson et al. 1979, Jones and Sullivan 1982, McPherson and McPherson 2000), we propose a single sampling plan to estimate stink bug density across species (i.e., C. hilaris and Euschistus spp.), life stages (i.e., nymph and adult), and locations in fields (i.e., edge and interior; Fig. 2).

\section{Required Sample Size for Population Estimates}

Calculated minimum required sample sizes for species, life stages, and field locations combined decreased with increasing stink bug density (Fig. 3). Based on all 549 data sets (i.e., samples), an ASN of 42 sets of 25 sweeps would be required to achieve a precision level of 0.25 for the range of stink bug densities commonly encountered in soybean across the region (i.e., $0.04-14.9$ stink bugs per 25 sweeps; Fig. 3A). 

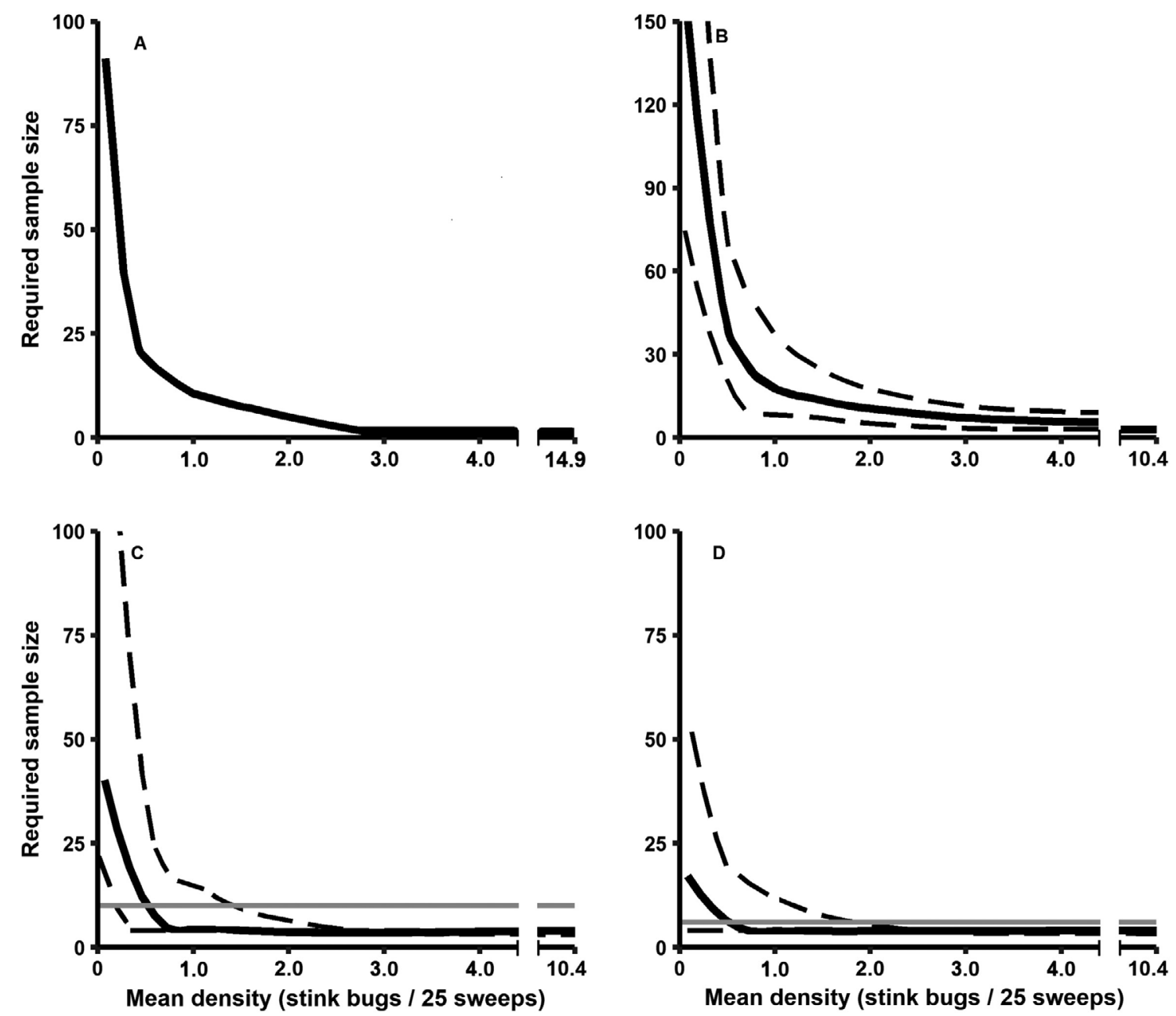

Fig. 3. Summary of required sample size for estimating stink bug density for all stink bug species, life stages, and field locations in soybean in the North Central Region of the United States. (A) Minimum sample size requirement based on 549 data sets for a desired precision level of 0.25. (B) Sample size requirement for a desired precision level of 0.25 with a resampling validation software. (C and D) Sampling plans for an average sample number (ASN) of 10 and 6 sample units, respectively, using resampling. Black solid lines indicate mean required sample size and dashed lines are maximum and minimum required sample sizes. Solid gray horizontal lines indicate desired ASN.

The combined sequential sampling plan described previously was validated through resampling of the 23 reserved data sets (Fig. 3B, Table 5). During resampling simulations, average achieved precision exceeded the desired level of 0.25 , so desired precision was relaxed to 0.28 to achieve an empirical precision of 0.25 , as was performed 
Table 5. Summary results for resampling validation of Green's sequential sampling plan for estimating mean density of stink bugs in soybean in the North Central Region of the United States, with desired fixed-precision level $=0.25$ for species, life stages, and field locations combined, and a desired average sample number (ASN) of 6 and 10 sample units at the mean density observed across the validation data sets (i.e., 1.8 stink bugs per 25 sweeps [range of 0.05-10.4 stink bugs per 25 sweeps])

\begin{tabular}{lcccrrr} 
& \multicolumn{2}{c}{ Precision } & & \multicolumn{3}{c}{ ASN } \\
\cline { 5 - 7 }$D$ & $D_{\min }$ & $D_{\max }$ & & $N$ & $N_{\min }$ & $N_{\max }$ \\
\hline 0.25 & 0.12 & 0.35 & 40 & 19 & 72 \\
0.43 & 0.04 & 0.77 & 10 & 4 & 34 \\
0.53 & 0.06 & 0.90 & 6 & 4 & 21 \\
\hline
\end{tabular}

by Burkness and Hutchison (1997), Galvan et al. (2007), and Tran and Koch (2017). Similarly, results based on the average of the samples used for validation showed that an ASN of 40 sets of 25 sweeps would be required to achieve a desired precision of 0.25 for stink bug densities ranging from 0.05 to 10.4 stink bugs per 25 sweeps (mean of 1.8 stink bugs per 25 sweeps; Fig. 3B, Table 5).

Because collection of approximately 40 and 42 sample units may be impractical for most applications, we calculated precision levels expected from more practical and commonly used sample sizes of 6 and 10 sample units (Table 1), which resulted in average precision levels of 0.54 and 0.43 , respectively, across the range of stink bug densities observed in this nine-state study (Fig. 3C and D, Table 5). Because the commonly recommended sample sizes resulted in precision levels greater than 0.25 , the use of those sampling recommendations may provide unreliable estimates for the average range of stink bug densities commonly observed across the North Central Region of the United States.

Although the objective of our study was to create a common sampling plan for estimating stink bug density in North Central Region soybean, our results show that required sample sizes changed abruptly with increasing densities, as observed in different states and soybean growth stages (Pezzini 2018). When densities were relatively low (i.e., $<0.5$ stink bugs per 25 sweeps), which was often the case when fields were in vegetative and early reproductive growth stages in northern states such as the Dakotas and Minnesota, as many as 109 sample units would have been required to obtain a desired precision level of 0.25 . Where densities were intermediate, one to three stink bugs per 
25 sweeps, which was observed in fields with growth stages of beginning seed-set through beginning maturity in Ohio and Michigan, fewer than 20 sample units would have been required. Last, where densities exceeded three stink bugs per 25 sweeps, which was observed in fields that had reached full seed-set in Nebraska, Missouri, and Indiana, as few as 5 sample units would have been needed to achieve a precision level of 0.25 .

Comparison of the present sample size requirements with previously published sampling plans is difficult because of the lack of studies using the same sampling methods (Souza et al. 2014, Babu and Reisig 2018). The contrast between statistically based sampling plans versus practical scouting recommendations is not unusual. A fixedprecision sampling plan for aster leafhopper, Macrosteles quadrilineatus Forbes (Hemiptera: Cicadellidae), in carrot, Daucus carota (L.) (Apiales: Apiaceae), estimated that 86 ten-sweep sample units and 5 ten-sweep sample units were required to estimate low $(<0.17 \mathrm{M}$. quadrilineatus per sweep) and high ( $\geq 0.17 \mathrm{M}$. quadrilineatus per sweep) leafhopper densities, respectively, at a precision level of 0.25 , compared with an extension recommendation of a total 100 sweeps (O'Rourke et al. 1998). In cotton, 88 sample units of 25 sweeps were estimated as necessary to reach a precision level of 0.30 for a density of one stink bug per 25 sweeps, but no sample size recommendation was available previously (Reay-Jones et al. 2009).

\section{Conclusions}

This is the first study to examine spatial patterns of stink bugs in soybean in the North Central Region of the United States and to develop and validate sampling plans for estimating stink bug population density in soybean in the region. Regression analyses of sample variances and means indicated that $\mathrm{C}$. hilaris and Euschistus spp. are aggregated in soybean fields in the North Central Region. Results for required sample size based on validation of data sets and on calculations using the entire data showed that an ASN of 40-42 25-sweep sample units would be necessary to achieve a desired precision of 0.25 (Fig. 3A and B).

Based on the gradient of stink bug densities found across the region, sampling in soybean in states in the southeastern part of the region where stink bug densities are higher may attain acceptable 
precision levels with relatively small sample sizes (6-20 sample units), which matches some of the current recommendations for stink bug scouting (Table 1). In contrast, in the northwestern part of the region where lower stink bug densities are generally encountered, current sampling recommendations for stink bugs (Table 1) may provide an inadequate level of precision, and prohibitively large sample sizes ( 100 sample units) would be required to achieve acceptable levels of precision (Fig. 3A and B). Practitioners should consider an arbitrary maximum number of sample units to balance cost (i.e., time) and reliability of estimates (i.e., precision) and to prevent never-ending sampling bouts when stink bug densities are very low. Further efforts to improve sampling plans for stink bug density estimation should evaluate different sample unit sizes (i.e., number of sweeps/sample unit) and costeffectiveness (i.e., time spent sampling) of alternate sampling plans. Knowledge of the extent of stink bug aggregation should guide the development of practical sequential binomial sampling plans for use by field scouts and growers who need to make stink bug treatment decisions when densities are near economic thresholds.

Acknowledgments - We are grateful to the numerous field and farm staff that maintained fields from which samples were collected; to James Menger, Kylie Rich, Pheylan Anderson, and Traci Eicholz (University of Minnesota), Lucinda Wallace and Priyanka Mittapelly (The Ohio State University), Nicole Luhr and Terry DeVries (University of Nebraska), Patrick Beauzay and Alexander Knudson (North Dakota State University), Taylor Nelson and Larry Bledsoe (Purdue University), Joe Gunn and Tanner Leslie (University of Missouri), and Stephen Losey (Kansas State University) for collecting and processing samples; and to Dan Cariveau, Emily Snell-Rood, and Eric Burkness for reviewing an earlier version of this manuscript. This research was funded by the Hueg-Harrison Fellowship awarded to D.T.P. and the North Central Soybean Research Program.

\section{References}

Aldrich, J. R., M. P. Hoffmann, J. P. Kochansky, W. R. Lusby, J. E. Eger, and J. A. Payne. 1991. Identification and attractiveness of a major pheromone component for Nearctic Euschistus spp. stink bugs (Heteroptera: Pentatomidae). Environ. Entomol. 20: 477-483.

Babu, A. 2018. Farmscape ecology of Euschistus servus (Hemiptera: Pentatomidae) in a corn, wheat, soybean ecosystem and development of a sampling plan in corn. Ph.D. dissertation, North Carolina State University, Raleigh, NC. 
Babu, A., and D. D. Reisig. 2018. Developing a sampling plan for brown stink bug (Hemiptera: Pentatomidae) in field corn. J. Econ. Entomol. 111: 1915-1926.

Bartoń, K. 2018. MuMIn: multi-model inference. R package version 1.40.4. https:// CRAN.R-project.org/package=MuMIn (accessed 16 April 2019).

Bates, D., M. Mächler, B. Bolker, and S. Walker. 2015. Fitting linear mixed-effects models using Ime4. J. Stat. Softw. 67: 1-48.

Boyd, M. L., and W. C. Bailey. 2000. Soybean pest management: stink bugs. University of Missouri Extension. http://extension.missouri.edu/publications/ DisplayPrinterFriendlyPub.aspx?P=g7151 (accessed 16 April 2019).

Burkness, E. C., and W. D. Hutchison. 1997. Development and validation of a binomial sequential sampling plan for striped cucumber beetle (Coleoptera: Chrysomelidae) in cucurbits. J. Econ. Entomol. 90: 1590-1594.

Canty, A., and B. D. Ripley. 2017. Boot: Bootstrap R (S-Plus) functions. R package version 1.3-20.

Cullen, E. 2012. Integrated pest and crop management. http://ipcm.wisc.edu/ blog/2012/08/stink-bug-nymphs-in-corn/ (accessed 16 April 2019).

Davis, P. M. 1994. Statistics for describing populations, pp. 33-54. In L. P. Pedigo and G. D. Buntin (eds.), Handbook of sampling methods for arthropods in agriculture. CRC Press, Boca Raton, FL.

DeCoursey, R. M., and C. O. Esselbaugh. 1962. Descriptions of the nymphal stages of some North American Pentatomidae (Hemiptera: Heteroptera). Ann. Entomol. Soc. Am. 55: 323-342.

Espino, L., M. O. Way, and L. T. Wilson. 2008. Determination of Oebalus pugnax (Hemiptera: Pentatomidae) spatial pattern in rice and development of visual sampling methods and population sampling plans. J. Econ. Entomol. 101: 216-225.

Esquivel, J. F., and E. G. Medrano. 2014. Ingestion of a marked bacterial pathogen of cotton conclusively demonstrates feeding by first instar southern green stink bug (Hemiptera: Pentatomidae). Environ. Entomol. 43: 110-115.

Evans, E. W. 1985. A key to nymphs of four species of the genus Podisus (Hemiptera: Pentatomidae) of northeastern North America. Proc. Entomol. Soc. Wash. 87: 94-97.

Fehr, W. R., and C. E. Caviness. 1977. Stages of soybean development. Spec. Rep. 80. Cooperative Extension Service, lowa State University, Ames, IA. 11 pp.

Galvan, T. L., E. C. Burkness, and W. D. Hutchison. 2007. Enumerative and binomial sequential sampling plans for the multicolored Asian lady beetle (Coleoptera: Coccinellidae) in wine grapes. J. Econ. Entomol. 100: 1000-1010.

Green, R. H. 1970. On fixed precision sequential sampling. Res. Popul. Ecol. 12: 249-251.

Greene, J. K. 2017. Soybean insect control, pp. 255-264. In M. Marshall, J. Greene, B. Bellinger, F. Reay-Jones, J. Mueller, D. Anco, P. Peterson, J. Tsuruda, C. Heaton, J. Crouch and B. Beer (eds.), 2017 South Carolina Pest Management Handbook. Clemson Cooperative Extension, Clemson University, Clemson, SC.

Harris, V. E., and J. W. Todd. 1980. Male-mediated aggregation of male, female and 5th instar southern green stink bugs and concomitant attraction of a Tachinid parasite, Trichopoda pennipes. Entomol. Exp. Appl. 27: 117-126. 
Hodgson, E. W., E. C. Burkness, W. D. Hutchison, and D. W. Ragsdale. 2004. Enumerative and binomial sequential sampling plans for soybean aphid (Homoptera: Aphididae) in soybean. J. Econ. Entomol. 97: 2127-2136.

Hunt, T., B. Wright, and K. Jarvi. 2011. Stink bug populations developing in soybeans and corn. CropWatch. University of Nebraska-Lincoln, Lincoln, NE. http://cropwatch.unl.edu/archive/-/asset_publisher/VHeSpfvOAgju/ content/4620945 (accessed 16 April 2019).

Hunt, T., B. Wright, and K. Jarvi. 2014. Stink bugs reported in corn and soybeans. CropWatch. University of Nebraska-Lincoln, Lincoln, NE. http://cropwatch.unl. edu/archive/-/asset publisher/VHeSpfvOAgju/content/stink-bugs-reported-innebraska-corn-and-soybeans (accessed 16 April 2019).

Hurley, T., and P. D. Mitchell. 2014. The value of neonicotinoids in North American agriculture: value of insect pest management to U.S. and Canadian corn, soybean, and canola farmers. Ag Informatics, Madison, WI. http://aginfomatics. com/index.html (accessed 16 April 2019).

Jones, W. A., Jr., and M. J. Sullivan. 1982. Seasonal abundance and relative importance of stink bugs in soybean. Techn. Bull. S. C. Agric. Exp. Stn. 285: 1-90.

Kiritani, K., N. Hokyo, K. Kimura, and F. Nakasuji. 1965. Imaginal dispersal of the southern green stink bug, Nezara viridula, in relation to feeding and oviposition. Jpn. J. Appl. Entomol. Zool. 9: 291-297.

Koch, R. L., and T. Pahs. 2014. Species composition, abundance, and seasonal dynamics of stink bugs (Hemiptera: Pentatomidae) in Minnesota soybean fields. Environ. Entomol. 43: 883-888.

Koch, R. L., and W. A. Rich. 2015. Stink bug (Hemiptera: Heteroptera: Pentatomidae) feeding and phenology on early-maturing soybean in Minnesota. J. Econ. Entomol. 108: 2335-2343.

Koch, R. L., D. T. Pezzini, A. P. Michel, and T. E. Hunt. 2017. Identification, biology, impacts and management of stink bugs (Hemiptera: Heteroptera: Pentatomidae) of soybean and corn in the midwestern United States. J. Integr. Pest Manag. 8: 1-14.

Kogan, M., and D. C. Herzog. 1980. Preface, pp. xi-xv. In M. Kogan and D. C. Herzog (ed.), Sampling methods in soybean entomology. Springer Verlag, New York, NY.

Kogan, M., and H. N. Pitre. 1980. General sampling methods for aboveground population of soybean arthropods, pp. 30-60. In M. Kogan and D. C. Herzog (eds.), Sampling methods in soybean entomology. Springer Verlag, New York.

Krupke, C., and J. Obermeyer. 2017. Green stink bug observed in southern Indiana soybean fields. Pest \& Crop Newsletter, Purdue Cooperative Extension Service. https://extension.entm.purdue.edu/pestcrop/2017/Issue23/ (accessed 16 April 2019).

Lampson, B. D., Y. J. Han, A. Khalilian, J. K. Greene, R. W. Mankin, and E. G. Foreman. 2013. Automatic detection and identification of brown stink bug, Euschistus servus, and southern green stink bug, Nezara viridula (Hemiptera: Pentatomidae) using intraspecific substrate-borne vibrational signals. Comput. Electron. Agric. 91: 154-159. 
Leskey, T. C., G. C. Hamilton, A. L. Nielsen, D. F. Polk, C. Rodriguez-Saona, J. C. Bergh, D. A. Herbert, T. P. Kuhar, D. Pfeiffer, G. P. Dively, C. R. R. Hooks, M. J. Raupp, P. M. Shrewsbury, G. Krawczyk, P. W. Shearer, J. Whalen, C. KoplinkaLoehr, E. Myers, D. Inkley, K. A. Hoelmer, D.-H. Lee, and S. E. Wright. 2012. Pest status of the brown marmorated stink bug, Halyomorpha halys, in the USA. Outlooks Pest Manage. 23: 218-226.

McPherson, J. E., and R. M. McPherson. 2000. Stink bugs of economic importance in America north of Mexico. CRC Press LCC, Boca Raton, FL.

McPherson, R. M., L. D. Newsom, and B. F. Farthing. 1979. Evaluation of four stink bugs species from three genera affecting soybean yield and quality in Louisiana. J. Econ. Entomol. 72: 188-194.

Michel, A., R. Bansal, and R. B. Hammond. 2015. Stink bugs on soybean and other field crops. Ohio State University Extension Fact Sheet, FC_ENT-x-13. https:// ohioline.osu.edu/factsheet/ENT-48 (accessed 16 April 2019).

Mississippi State University. 2019. Insect control guide for agronomic crops. http://extension.msstate.edu/sites/default/files/publications/publications/ p2471web.pdf (accessed 16 April 2019).

Moon, R. D., and L. T. Wilson. 2008. Sampling for detection, estimation and IPM decision making, pp. 75-89. In E. B. Radcliffe, W. D. Hutchison, and R. E. Cancelado (eds.), Integrated pest management: concepts, tactics, strategies, and case studies. Cambridge University Press, Cambridge, United Kingdom.

Nakasuji, F., N. Hokyo, and K. Kiritani. 1965. Spatial distribution of three plant bugs in relation to their behavior. Res. Popul. Ecol. 7: 99-108.

Naranjo, S. E., and H. M. Flint. 1994. Spatial distribution of preimaginal Bemisia tabaci (Homoptera: Aleyrodidae) in cotton and development of fixed-precision sequential sampling plans. Environ. Entomol. 23: 254-266.

Naranjo, S. E., and W. D. Hutchison. 1997. Validation of arthropod sampling plans using a resampling approach: software and analysis. Am. Entomol. 43: 48-57.

O'Rourke, P. K., E. C. Burkness, and W. D. Hutchison. 1998. Development and validation of a fixed-precision sequential sampling plan for aster leafhopper (Homoptera: Cicadellidae) in carrot. Environ. Entomol. 27: 1463-1468.

Paiero, S. M., S. A. Marshall, J. E. McPherson, and M.-S. Ma. 2013. Stink bugs (Pentatomidae) and parent bugs (Acanthosomatidae) of Ontario and adjacent areas: a key to species and a review of the fauna. Can. J. Arthropod Identif. 24: 1-183.

Panizzi, A. R., J. E. McPherson, D. G. James, M. Javahery, and R. M. McPherson. 2000. Stink bugs (Pentatomidae), pp. 421-474. In C. W. Schaefer and A. R. Panizzi (eds.), Heteroptera of economic importance. CRC Press, Boca Raton, FL.

Payton, M. E., M. H. Greenstone, and N. Schenker. 2003. Overlapping confidence intervals or standard error intervals: what do they mean in terms of statistical significance? J. Insect Sci. 34: 1-6.

Pedigo, L. P., and M. E. Rice. 2009. Entomology and pest management. Prentice Hall, Upper Saddle River, NJ.

Pezzini, D. T. 2018. Community characterization and development of a sampling plan for stink bugs (Hemiptera: Pentatomidae) in soybean in the North Central Region of the U.S. M.S. thesis, University of Minnesota, Minneapolis, MN. 
Pilkay, G. L., F. P. F. Reay-Jones, M. D. Toews, J. K. Greene, and W. C. Bridges. 2015. Spatial and temporal dynamics of stink bugs in southeastern farmscapes. J. Insect Sci. 15: 10-23.

R Core Team. 2018. R: a language and environment for statistical computing. R Foundation for Statistical Computing, Vienna, Austria. https://www.Rproject. org/ (accessed 16 April 2019).

Ragsdale, D. W., B. P. McCornack, R. C. Venette, B. D. Potter, I. V. MacRae, E. W. Hodgson, M. E. O'Neal, K. D. Johnson, R. J. O'Neil, C. D. DiFonzo, et al. 2007. Economic threshold for soybean aphid (Hemiptera: Aphididae). J. Econ. Entomol. 100: 1258-1267.

Raudenbush, A., A. Michel, and K. Tilmon. 2017. Stink bugs on soybean in the North Central Region. North Central Soybean Research Program (NCRSP). http://soybeanresearchinfo.com/pdf docs/Stinkbugs of the Northcentral Region_2017.pdf (accessed 16 April 2019).

Reay-Jones, F. P. F. 2014. Spatial distribution of stink bugs (Hemiptera: Pentatomidae) in wheat. J. Insect Sci. 14: 1-22.

Reay-Jones, F. P., J. K. Greene, M. D. Toews, and R. B. Reeves. 2009. Sampling stink bugs (Hemiptera: Pentatomidae) for population estimation and pest management in southeastern cotton production. J. Econ. Entomol. 102: 2360-2370.

Reeves, R. B., J. K. Greene, F. P. Reay-Jones, M. D. Toews, and P. D. Gerard. 2010. Effects of adjacent habitat on populations of stink bugs (Heteroptera: Pentatomidae) in cotton as part of a variable agricultural landscape in South Carolina. Environ. Entomol. 39: 1420-1427.

Reisig, D. 2017. Scouting for insects. https://soybeans.ces.ncsu.edu/scouting-forinsects/ (accessed 16 April 2019).

Rice, K. B., C. J. Bergh, E. J. Bergmann, D. J. Biddinger, C. Dieckhoff, G. Dively, H. Fraser, T. Gariepy, G. Hamilton, T. Haye, et al. 2014. Biology, ecology, and management of brown marmorated stink bug (Hemiptera: Pentatomidae). J. Integr. Pest Manag. 5: A1-A13.

Rider, D. A. 2012. The Heteroptera (Hemiptera) of North Dakota I: Pentatomomorpha: Pentatomoidea. Great Lakes Entomol. 45: 312-380.

Sane, I., D. R. Alverson, and J. W. Chapin. 1999. Efficiency of conventional sampling methods for determining arthropod densities in close-row soybeans. J. Agric. Urban Entomol. 16: 65-84.

Southwood, T. R. E. 1978. Ecological methods, with particular reference to the study of insect populations. Chapman \& Hall, London, United Kingdom.

Souza, L. A., J. C. Barbosa, J. F. J. Grigolli, D. F. Fraga, L. C. Moraes, and A. C. Busoli. 2014. Sequential sampling of Euschistus heros (Heteroptera: Pentatomidae) in soybean. Sci. Agric. 71: 464-471.

Stewart, S., A. T. McClure, and R. Patrick. 2010. Soybean insects - stink bugs. Extension article, University of Tennessee. https://extension.tennessee.edu/ publications/Documents/W200.pdf (accessed 16 April 2019).

Taylor, L. R. 1961. Aggregation, variance and the mean. Nature 189: 732-735. 
Tillman, P. G., T. D. Northfield, R. F. Mizell, and T. C. Riddle. 2009. Spatiotemporal patterns and dispersal of stink bugs (Heteroptera: Pentatomidae) in peanutcotton farmscapes. Environ. Entomol. 38: 1038-1052.

Tillman, P. G., J. R. Aldrich, A. Khrimian, and T. E. Cottrell. 2010. Pheromone attraction and cross-attraction of Nezara, Acrosternum, and Euschistus spp. stink bugs (Heteroptera: Pentatomidae) in the field. Environ. Entomol. 39: 610-617.

Todd, J. W., and D. C. Herzog. 1980. Sampling phytophagous Pentatomidae on soybean, pp. 438-478. In M. Kogan and D. C. Herzog (eds.), Sampling methods in soybean entomology. Springer, New York.

Tran, A. K., and R. L. Koch. 2017. Spatial patterns and sequential sampling plans for predators of Aphis glycines (Hemiptera: Aphididae) in Minnesota Soybean. Environ. Entomol. 46: 663-673.

(USDA-NASS) U.S. Department of Agriculture-National Agricultural Statistics Service. 2018. Agricultural chemical use survey: soybeans. https://www.nass. usda.gov/Surveys/Guide to NASS Surveys/Chemical Use/2017 Cotton Soybeans Wheat Highlight/ChemUseHighlights Soybeans 2017.pdf (accessed 16 April 2019).

Venugopal, P. D., P. L. Coffey, G. P. Dively, and W. O. Lamp. 2014. Adjacent habitat influence on stink bug (Hemiptera: Pentatomidae) densities and the associated damage at field corn and soybean edges. PLoS One 9: e109917.

Vinatier, F., P. Tixier, P.-F. Duyck, and F. Lescourret. 2011. Factors and mechanisms explaining spatial heterogeneity: a review of methods for insect populations. Methods Ecol. Evol. 2: 11-22.

Vyavhare, S. S., M. O. Way, A. Knutson, S. Biles, and R. A. Pearson. 2015. Managing soybean insects in Texas. Texas A\&M AgriLife Extension. https://agrilifecdn. tamu.edu/extensionento/files/2017/06/J35419-TAMU-Managing-SoybeanInsects-1.pdf (accessed 16 April 2019).

Wilson, L. T. 1985. Estimating the abundance and impact of arthropod natural enemies in IPM systems, pp. 303-322. In M. A. Hoy and D. C. Herzog (eds.), Biological control in IPM systems. Academic Press, Orlando, FL.

Wiman, N. G., V. M. Walton, P. W. Shearer, S. I. Rondon, and J. C. Lee. 2015. Factors affecting flight capacity of brown marmorated stink bug, Halyomorpha halys (Hemiptera: Pentatomidae). J. Pest. Sci. 88: 37-47.

Zar, J. 1999. Biostatistical analysis. Prentice Hall, Upper Saddle River, NJ. 